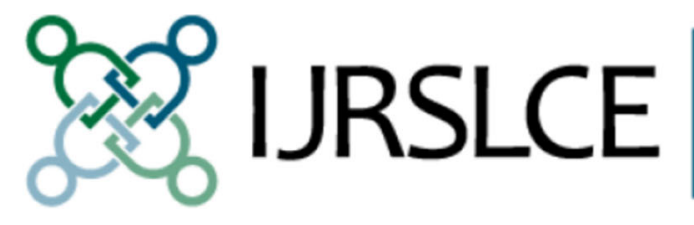

International Journal

for Research on

Service-Learning \&

Community Engagement

\title{
Community-Based Service-Learning: A Rural Australian Perspective on Student and Academic Outcomes of Participation
}

\section{Debra Jones \\ Lindy McAllister \\ David Lyle}

This article was originally published at:

https://journals.sfu.ca/iarslce/index.php/journal/article/view/236/168

Recommended Citation

Jones, D., McAllistter, L., \& Lyle, D. (2016). Community-based service-learning: A rural Australian perspective on student and academic outcomes of participation. International Journal of Research on Service-Learning and Community Engagement, 4(1), 181-198. 


\title{
Community-Based Service-Learning: A Rural Australian Perspective on Student and Academic Outcomes of Participation
}

\author{
Debra Jones \\ Lindy McAllister \\ David Lyle \\ University of Sydney
}

\begin{abstract}
This article reports on a community-based service-learning program that aligned occupational therapy and speech pathology student learning with service provision in order to address the unmet developmental needs of children residing in rural New South Wales, Australia. The article describes academy outcomes for participating allied health students and academics. A pragmatic qualitative research study was undertaken and data collected through focus groups with students and individual interviews with academics. Data were analyzed using a constant comparative analysis method. Broad codes were developed and then collapsed into two themes: catalysts for program participation and civic impacts of participation. Based on the study findings, the authors argue for the need to ensure the development of communityliterate health students, academics, and practicing professionals if colleges and universities are to create a rural-ready and responsive health workforce. This community-literate approach must inform how Australian higher education institutions engage with rural communities in community-based servicelearning innovation.
\end{abstract}

Keywords: community literate, health workforce development, occupational therapy, rural Australia, service-learning, speech pathology, university departments of rural health

Service-learning in pre-registration education is gaining momentum across Australian higher education (Birbeck, 2012; Caspersz, Olaru \& Smith, 2012; Coffey \& Lavery, 2015; Hammersley, 2012; Langworthy, 2007). In rural and remote (referred to as rural throughout this paper) Australia, communitybased service-learning models, including community-based interprofessional service-learning models, are being developed by University Departments of Rural Health as an additional approach to hospital-based education for health students (Jones et al., 2015; Mason, 2013). A number of factors have led to the emergence of rural community-based service-learning including: increased demand for traditional and non-traditional placements to meet the educational requirements of greater numbers of health students responding to national health workforce shortages (Health Workforce Australia [HWA], 2013b; Jones et al., 2015; Mason, 2013); the exploration of alternative models that promote positive learning experiences in regional community-based primary healthcare settings (HWA, 2013a) to promote student intent to practice in rural settings post-graduation (Deaville \& Grant, 2011; O'Brien, Phillips, \& Hubbard, 2010); and the need for better alignment between health education and contemporary rural healthcare practices and community expectations (HWA, 2013a; Standing Council on Health [SCoH], 2013). Communitybased service-learning models are underpinned by mutually beneficial and reciprocal outcomes for student learning and community service recipients (Eyler \& Giles, 1999; Jacoby, 1996).

\section{Defining and Describing Service-Learning}

Service-learning has been an acknowledged pedagogy in the United States for a number of decades (Beatty, 2010) and has been described as "a philosophy of service and learning that occurs in experiences, 
reflection, and civic engagement within collaborative relationships involving community partners" (Flecky, 2011, p. 1). Service-learning provides opportunities for community agencies and education institutions to work collaboratively on initiatives that draw on and contribute to student development of discipline knowledge and technical skills (Lenk, 1997; Zlotkowski, 1995) through the provision of student services that align with community-identified health needs (Eyler \& Giles, 1999; Jacoby, 2003; Sessa, Grabowski, \& Shashidar, 2013).

A diversity of service-learning definitions have been proposed within the literature (e.g., see Cipolle, 2010; Jacoby, 1996). Bringle and Hatcher (2009) defined service-learning as:

A course-based, credit bearing educational experience in which student's (a) participate in an organized service activity that meets identified community needs and (b) reflect on the service activity in such a way as to gain further understanding of the course content, a broader appreciation of the discipline, and an enhanced sense of civic responsibility. (p. 38)

Recently, the definition of service-learning has been expanded to include approaches that align service-learning with interprofessional education aims. Clark et al. (2015) stated that "service-learning aims to recognize and respond to societal needs" and that "interprofessional education aims to form teams to meet those needs" (p. 2). For the purposes of this study, the authors adopted Bringle and Hatcher's (2009) service-learning definition with the addition of interprofessional learning and practice aims; learning that enhances student knowledge and understanding of teamwork to enable discipline-specific and interprofessional practice that draws on student technical skills in team service provision.

A number of beneficial student outcomes have been associated with community-based servicelearning initiatives. These benefits include heightened awareness of civic and social responsibility (Kendrick, 1996), increased student desire to be civically engaged (Jacobson et al., 2011), enhanced academic and critical thinking (Astin \& Sax, 1998; Eyler \& Giles, 1999), development of self-esteem and personal efficacy (Astin \& Sax, 1998), and enhanced understanding of community issues (Brown, Heaton, \& Wall, 2007). According to the literature, service-learning is intrinsically linked to engagement with communities and their contribution to student learning outcomes (Bringle \& Hatcher, 1996; Jacoby, 1996).

\section{Service-Learning and the Australian Context}

As an emerging approach to student education in Australia, service-learning innovations are heavily informed by literature, experience, and evidence from the United States. This creates a number of complexities when considering the lack of clarity and a universally accepted definition of service-learning and its objectives (Butin, 2010), limited service-learning experience and evidence to inform higher education strategic and educational frameworks (Birbeck, 2012), and differing educational, historical, and cultural environments (Langworthy, 2007). This article aims to inform Australian higher education's understanding of, and approaches to, community-based service-learning.

\section{University Departments of Rural Health}

A number of university departments of rural health - key stakeholders in rural health workforce development and education (Mason, 2013) - have invested in community-based service-learning models. These models seek to align pre-registration health education for students with service provision that addresses community-identified health needs within their footprints (Jones et al., 2015; Mason, 2013). Selected models have been adapted within rural Australian contexts and have moved students beyond the patient bedside into collaborative work with community agencies. Although university departments of rural health have extended their engagement in service-learning innovation, the strategic success of this program is routinely measured by impacts on student intent to practice in rural settings and whether students take up rural practice post-graduation. Less emphasis has been placed on the learning outcomes 
that may be achieved through student engagement with rural communities, student contributions to enhanced service accessibility, and the resultant health outcomes of communities.

\section{The Service-Learning Program}

The program at the center of this study, Allied Health in Outback Schools, was initiated in 2009 in response to concerns raised by community leaders, namely primary school principals, about the detrimental educational, health, and social outcomes for children experiencing developmental delays who were unable to access allied health services. Rural Australian communities can experience difficulty in the recruitment and retention of allied health professionals, which has direct implications for service accessibility (Spiers \& Harris, 2015). Therefore, a cross-sector partnership was established between local health and school education sectors, and the Broken Hill University Department of Rural Heal, a rural department of the University of Sydney. Representatives from the university's Faculty of Health Sciences, with responsibility for allied health education, contributed to the development of a communitybased and interprofessional service-learning program. Partners identified early potential program benefits, including improved service accessibility, enhanced child developmental outcomes, growth in rural placement capacity (HWA, 2013b), enhanced student learning outcomes, and student exposure to primary healthcare practices (HWA, 2013a).

Serial cohorts of final-year occupational therapy and speech pathology students from four Australian universities now participate in the program across the four school terms. Students provide screening, assessment, therapy, and referral services, drawing on the work of previous student cohorts to inform service delivery. This approach creates a "team continuum" (Jones et al., 2015a) that increases the continuity of student service delivery. Supervision approaches include discipline and interprofessional supervision, student peer supervision, and school teacher supervision. Learning and service occur onsite at the university department of rural health and at 12 school campuses across three regional communities. Approximately 150 preschool and primary school children access this service annually. Students participate in an intensive five-day orientation to the placement program prior to entering school settings, as well as weekly clinical and professional reflection sessions. Mid- and end-of-placement focus group evaluations are conducted by an independent facilitator to guide student reflection and identification of potential areas of program improvement. (For more information about the program and its evolution, see Jones et al., 2015).

Despite the perceived multidimensional benefits of community-based service-learning (Budhai, 2013; Caspersz et al., 2012; Cruz \& Giles, 2000; Hammersley, 2012; Steinberg, Bringle, \& Williams, 2010) limited evidence exists within the Australian literature about the impacts and outcomes of participation for higher education students and faculty. Although a number of internal evaluations of the Allied Health in Outback Schools program have been undertaken, no formal studies have explored the impact of participation on allied health students, occupational therapy and speech pathology, and academics engaged in this program or other service-learning programs being delivered within the Australian context, specifically rural Australian contexts.

\section{The Study}

This qualitative study used a pragmatic approach (Sandelowski, 2000; Smith, Bekker \& Cheater, 2011). Pragmatic research is driven by the phenomenon under investigation and guided by the adoption of research approaches and methods that best enable the aims of the study to be addressed (Morgan, 2014). Since this study did not seek to view the world in terms of absolutes and was not committed to a single philosophy or understanding of reality, the methods utilized were those considered best suited to obtaining, analyzing and interpreting the data.

The aim of this study was to better understand the impacts and outcomes of participation in the community-campus partnership and service-learning program, which was informed by community and campus participants. Through this study, we hoped to contribute a rural perspective to the growing 
service-learning discourse in Australian higher education. This article focuses on academy outcomes for participating occupational therapy and speech pathology students and allied health academics, with a specific focus on factors that influenced stakeholder participation and on the impacts of this participation.

Low-risk ethics approval was granted by the University of Sydney's Human Research Ethics Committee, the NSW Department of Education and Communities (NSW DEC), the Catholic Education Office, and La Trobe University.

\section{Participants}

Participants selected for this study included occupational therapy $(n=4)$ and speech pathology $(n=6)$ students, who represented one student cohort undertaking its placement in one school term in 2014, and allied health academics - one in a rural setting who had over three years of responsibility for the direct education and supervision of students engaged in the service-learning program, and one in metropolitan setting who had contributed to the development of the program and had a continuing strategic partnership and programmatic role. Students and academics were sent introductory emails through their university email accounts by an independent university administration officer. The email contained participant information sheets, consent forms, and additional details from the lead investigator about the study. Signed consent forms were returned to the administration officer. All students $(n=10)$, from two different universities, and both academics $(n=2)$ consented to participate in the study. All data were collected in the latter half of 2014.

\section{Design}

Focus groups and individual semi-structured interviews were conducted to support the pragmatic responsiveness of the study, the parallel use of data to enable data comparison, and the researchers' desire for data completeness (Lambert \& Loiselle, 2008).

\section{Focus groups}

Occupational therapy and speech pathology students were purposefully allocated to one of two interprofessional focus groups (FGs) reflecting program design (two occupational therapy students and three speech pathology students in each group). The FGs were selected to elicit the shared experience of student participants. Each FG ran for approximately 60 minutes, was facilitated by an independent qualitative researcher (Creswell, 2007), and was conducted onsite at the Broken Hill University Department of Rural Health. The facilitator used a prepared schedule of questions that had been developed from previous student cohort mid- and end-of-placement FG evaluations and from the research aims. Specifically, questions focused on:

- factors that influenced program participation;

- perception of what the placement entailed;

- comparison of the placement with previous placement experiences;

- impact of participation in the program;

- perceptions of program aims;

- how participants would describe the program to others;

- recommendations for program improvement; and,

- perceptions of future program direction.

\section{Semi-structured individual interviews}

Academics participated in individual, semi-structured interviews. The rural academic's interview was conducted face-to-face at the University Department of Rural Health, while the metropolitan academic's was held via teleconference. Each interview ran for approximately 50 minutes. The same independent qualitative researcher facilitated both interviews using a prepared schedule of questions developed from 
previous academic program feedback and the research aims. A level of variation existed between academic questions based on operational and strategic program roles. Semi-structured individual interviews were selected due to these variations, differing levels of seniority, and geographical separation. Academic questions reflected those asked in student FGs, excluding questions 2 and 3.

Follow-up questions were asked during FGs and individual interviews as needed to promote greater participant feedback. FGs and individual interviews were digitally recorded, then transcribed manually; the transcripts were then provided to the academics for verification (Lincoln \& Guba, 1985). Students were de-identified by discipline and university due to the small sample size and placement location to ensure confidentiality. Students were allocated FG and student numbers (i.e., FG1: Student 1, FG2: Student 2, etc.). Academics were de-identified by discipline to ensure confidentiality based on the small number of participants, and identifiers were allocated (i.e., rural academic and metropolitan academic).

\section{Data Analyses}

Data were analyzed using a constant comparative analysis method (Fram, 2013; O'Connor, Netting, \& Thomas, 2008). The authors used a pragmatic approach to adapt this method (Boeije, 2002) in an effort to ensure its applicability to this study. This resulted in four stages of analysis: (1) comparison within single transcripts; (2) comparison within group transcripts (principal, senior manager, allied health student, and academic groups); (3) comparison within community and campus group transcripts (principals and senior managers, allied health students, and academics); and (4) comparison across community and campus transcripts. Three researchers independently reviewed a selection of campus transcripts, coded and categorized data, and identified emerging themes. All of the researchers reviewed and re-analyzed results to refine descriptions of themes (Creswell, 2007). The remaining transcripts were then analyzed by the lead investigator.

\section{Results}

Two themes - catalysts for program participation and civic impacts of participation-were identified through Stage-3 analysis of campus data (i.e., comparison between allied heath student and academic transcripts). Table 1 lists the themes and subthemes that emerged from the analysis.

Table 1. Themes and Subthemes

1. Catalysts for program participation

2. Civic impacts of participation
1. University-led allocation of student participation

2. Student self-selection for participation

3. Pull of rural location

4. Service equity for rural populations

1. Community knowledge and connectedness

2. Academic credibility and continuity of engagement

3. Professional satisfaction and faculty pride

4. Service-learning implications

In the following sections, the themes and subthemes are described in greater detail using direct quotations from participants. A discussion of findings is provided at the end of each subtheme. 


\section{Theme 1: Catalysts for Program Participation}

This theme contained four subthemes: university-led-allocation of student participation, student-selfselection for participation, the pull of rural location, and service equity for rural populations.

\section{Subtheme 1: University-led-allocation of student participation}

A number of students identified the role of their university in placement allocation: "I didn't allocate to be here. I had a couple of other places where I suggested I could go" (FG2: Student 2). They also discussed the process associated with informing students of what they perceived to be a "randomly allocated" (FG2: Student 1) placement: "We got an email saying that we were placed here. We just got told. We had to pack our bags and 12 hours later we got here" (FG1: Student 2).

Subtheme discussion. The use of university-led allocation, although perceived as "random" by some students, may reflect the university's commitment to ensuring sufficient student numbers to meet the service requirements of the program. Universities also need to ensure a breadth of student experiences that address professional registration requirements, including rural experiences. This university-led allocation could hold potential risks for students when their choice and voice have not influenced their placement allocation as well as for host community agencies if students reflect a level of antipathy toward their "random allocation" (National Rural Health Alliance (NRHA), 2004). In relation to student impact of participation in this program, all students identified positive learning outcomes associated with their experience, and no negative feedback was reported by host community agencies about students' approaches to their placement. However, careful consideration must be given to ensuring that students are fully informed of the rationales for placement allocation to avoid perceptions of "randomness" and the potential for less-than-optimal learning outcomes.

\section{Subtheme 2: Student self-selection for participation}

Students who self-selected identified a number of influential factors, including knowledge of previous student experiences and program promotion by university placement coordinators, described as "word of mouth" (FG1: Student 3) program promotion:

- We had heard good things from previous students. They said it was an excellent placement to work on. We all [preferred] this placement first. (FG2: Student 5)

- Our placement coordinator made an emphasis on the advantages of service-learning placements, that it would be beneficial for us to get that experience. (FG1: Student 3)

One participant discussed the role of a previous student in reducing student pre-placement anxieties:

One of the [previous students] sent me an email outlining everything you needed to know [about the program]. It took away the anxiety. I previously had quite a challenging placement and [they were] aware of that. [They] really built me up and said, "You're going to love it, it'll be fantastic." (FG1: Student 3)

Another student described his or her perception of program status within his or her home university as an influencing factor for self-selection:

Our university thinks very highly of the program, so they encouraged us to do it. We were given information that it was intensive, it entailed working five days a week and that it was a wonderful experience. We had the choice to put our names down. (FG2: Student 1)

Subtheme discussion. As the study findings suggest, access to rural placements for students with a preference for rural experiences can rely on student, academic, and placement coordinator knowledge of placement availability. Indeed, inadequate knowledge is considered a barrier to student selection of rural 
placements (Spiers \& Harris, 2015). The findings also suggest that "word of mouth" promotion by previous students and placement coordinators can directly influence student self-selection and act to mitigate potential pre-placement student anxieties. Finally, it appears that positive perceptions of program quality and student learning outcomes associated with service-learning participation contributed in this study to program promotion and student placement selection.

\section{Subtheme 3: The pull of rural location}

Study participants discussed student self-selection for a specific rural experience as an additional catalyst for their participation in the program: "I chose this placement based on the rural location. I wanted experience with a rural placement" (FG1: Student 3). They also highlighted their perception of a rural placement as being different from previous metropolitan placements: "Rural is something different. I think it added an element of adventure to the whole placement. That made me want to come here" (FG2: Student 4). In addition, students discussed a perceived lack of alternative choice for rural placements:

There weren't an awful lot of rural placements to pick from to be completely honest. There were about 30 of us and there were four places here and places in larger regional and metropolitan centers. Our options were limited. Out of those options Broken Hill was my first preference. (FG1: Student 2)

The rural academic indicated that a preference for rural work influenced his or her relocation to the community to take up an academic position:

I'd always been interested in rural work. I was looking for another rural job. I'd passed through this community before. It looks very similar to another rural community I had lived and worked in. Coming back here felt right.

Subtheme discussion. The "pull" of rural location appears to have influenced student self-selection for placement and employment preference for the rural academic. Decreased competiveness in accessing client experiences (HWA, 2013b), diversity of clients, and perceptions of autonomy in practice (Van Hofwegen, Kirkham \& Harwood, 2005) have been identified as pull features for student self-selection for rural placement. Scarcity of rural placement opportunities (Spiers \& Harris, 2015) may also contribute to a sense of student competitiveness in accessing these opportunities. There is less evidence available describing the influence of rural location on work preference for existing health professionals and academics as factors that contribute to their engagement. The authors propose that rurally located university departments of rural health may contribute to the recruitment and retention of "difficult to access" health professionals within these regions. The establishment of positions that incorporate clinical and academic roles may prove attractive to rural-orientated health professionals seeking to extend their careers.

\section{Subtheme 4: Service equity for rural populations}

The metropolitan academic described how he or she first became engaged in the program and his or her initial program role:

A colleague put a Broken Hill University Department of Rural Health staff member in contact with me. My role when the program first started was faculty sponsor. I had the capacity to make our contribution happen. I had a little discretionary funding to initially support the program.

This academic then went on to describe his or her professional and research interest in rural health:

I have a research interest in rural health and a passion about equity of access to services for people in rural areas. This program was a match made in heaven. I've learnt through being 
involved in this program and talking with local stakeholders that there's a process involved. We had a discussion right in the very beginning about no research until we'd won the trust of the community.

The rural academic stressed the importance of equity in service accessibility for rural populations: "I think this position has really enabled me to offer services that best meet the needs of rural individuals as opposed to everyone getting an equal share, it's more responsive."

Subtheme discussion. Individuals residing in rural Australian communities are more likely to experience lower socioeconomic status (Simon et al., 2013), lower levels of educational attainment (NSW DEC, 2013), and poorer health outcomes - all acknowledged precursors to developmental delay (Council of Australian Governments [COAG], 2009). Children residing in rural areas are also less likely to have access to pediatric allied health services to address these needs (Allied Health Professionals Australia [AHPA], 2013; NSW DEC, 2013; Spiers \& Harris, 2015), as was the case in far western New South Wales. The importance of providing health services to these children to ensure the best possible start in life and enhanced later-life outcomes has been described in the Australian and international literature (COAG, 2009; Irwin, Siddigi \& Hertzman, 2007; Simon et al., 2013). The locally identified need to resolve protracted allied health service inequities has emerged as the primary catalyst for partnership formation and program development. However, addressing complex inequities in resource-limited environments can prove challenging. The Broken Hill University Department of Rural Health drew on its academic networks to facilitate local partner engagement with a large metropolitan university (i.e., the University of Sydney Faculty of Health Sciences) with significant intellectual, social, and human resources to identify and implement solutions. This enabled the linking of the metropolitan-based academic, who possessed a rural interest, with the community partnership.

Providing evidence of the impact of Australian community-based service-learning is critical to the transferability and adaptability of this pedagogy. However, high levels of sensitivity must be employed by researchers when considering research agendas in rural locations. Mutual trust must be established and strategies employed to avoid an academy-dominated research agenda (Budhai, 2013; Cruz \& Giles, 2000). Additional challenges arise when student and academic self-selection bias for service-learning or rural engagement influence research findings (Steinberg et al., 2010), and these inclinations need to be controlled in research studies to avoid over-interpretation of results (Astin \& Sax, 1998). Student participants in this study self-identified as representing a mix of university-allocated and self-selected participants, potentially enhancing the broader generalizability of study findings, whereas both academics described their preference for, or interest in, rural health.

\section{Theme 2: Civic Impacts of Program Participation}

This theme contained four subthemes: community knowledge and connectedness, academic credibility and continuity, professional and faculty satisfaction, and service-learning implications.

\section{Subtheme 1: Community knowledge and connectedness}

Students described the attainment of rural community knowledge from a peer critique perspective - that is, critiquing their peers who were non-program participants but also undertaking a rural placement in the region:

You have some health students who come out here and this is way too remote for them. They don't need the hassle and change. They are city folk who can't really adapt. It's great that they take the opportunity so at least they know what rural practice is like. (FG2: Student 3)

Students described their own sense of community connectedness: "I've loved the placement. Going home is going to be really difficult. I don't want to go home, I'm really quite content here" (FG2: Student 
1). This student also commented on his or her observations regarding the connectedness of community members:

Everyone asks what you're doing here, they know that you're students. They say, "You must be the health students. What are you doing?" We're working in the schools, "Oh, I know so and so." We even get the kids that say, "Oh, do you know this child because they get therapy from you." (FG2: Student 1)

Students also described the relatively quick adoption and use of local community idioms:

I love the learning from local people's perceptions. Melbourne, Adelaide, and Sydney aren't that far, local people don't know what the big deal is, but just over the hill is far away. I'm like, "What do you mean?" I started saying that in my third week of placement-over the hill is so far away. (FG1: Student 1)

The metropolitan academic described the impact of knowledge sharing by a community leader on his or her insight into the community's experience with service inequity:

One of the school principals said to me, "Will we ever see you again? That's what happens with allied health professionals, they come once and then you never see them again." Talking to the principals took it to another level. I came away feeling very determined that I was going to help be part of the solution.

The rural academic provided a description that reflected his or her desire to ensure connectivity with the community:

I've tried to engage with the community as much as possible; otherwise, you would be professionally isolated. I make a really strong point of being approachable in social settings and friendly so community members will approach me.

The metropolitan academic described the unique student benefits associated with gaining deeper knowledge of and experience with rural communities:

There is the dimension of student learning about rural communities, their challenges, their joys, their benefits and the difference in culture. In our faculty, a small percentage of students are of rural origin. We have a lot of international students who typically never go [rural], ever. For those students this program is an amazing eye-opening experience.

Subtheme discussion. Participants described a number of deep community insights that the authors attribute to the attainment of a sense of belonging within the program and broader community context. Levett-Jones et al. (2008) argued that a sense of belonging is important to a student's "fitting in" to their placement context. To achieve this perceived belonging, students require adequate time to settle into their host facilities and familiarize themselves with personnel, workplace culture, and practices. Once settled, it has been observed that students often progress from feeling like an outsider to feeling like an accepted team member, enhancing their confidence and engagement in learning activities (Levett-Jones et al., 2008). The authors propose that this sense of belonging can be extended to include student and academic belonging within rural community contexts. Rural placements and partnerships can challenge metropolitan-oriented students and academics, requiring a period of time to adapt to rural community identities, culture, and practices.

\section{Subtheme 2: Academic credibility and continuity of engagement}


Students reflected on the importance of their professional credibility as service providers to rural pupils and families:

I know we're only students and we're not professionals. We haven't been doing this forever and we don't have all the experience, but for the pupils to be receiving services at all is amazing. I think we provide them with more services than what they would possibly be able to receive otherwise. Their parents can't take them to a specialist; they're not going to be able to receive that care here. (FG1: Student 3)

Students also described the continuity of activity between student cohorts: "Each cohort [has] been doing the same thing, so you just have to keep doing it so that the next cohort knows exactly what to do" (FG1: Student 2).

The metropolitan academic described his or her concerns about loss of community credibility when a failure to meet commitments occurred early in program development:

We couldn't fulfil our obligations to the second cohort of students. I was absolutely mortified. I thought [the] community might have given up on us, but they didn't. We regrouped and the next year we ran across the whole year with students. I think we won back the faith of the school principals in that year.

Both academics identified the importance of maintaining continuity of engagement with the community and the program through ongoing direct or indirect actions at the strategic and operational levels. The metropolitan academic described his or her current relationship with community initiatives:

I was at a meeting where people from the university were sounding out the other faculties about whether they were interested in engaging with Broken Hill on a wider scale. I spoke about our experiences, how great it had been and what our students were getting out of it. It was a watershed moment for me.

The rural academic identified the importance of continuity of engagement with key stakeholders at the local level:

I try and keep across 12 campuses and the relationships with all of those teachers. That's what I was doing this morning, getting out, going around saying hello to all the teachers again.

Subtheme discussion. In the literature, service-learning partnerships have been described as existing along a continuum of risk and benefit - that is, low-risk activity, low benefit; high-risk activity, high benefit (Enos \& Morton, 2003). Establishing rural-metropolitan partnerships between academic departments and local agencies can be considered a high-risk endeavor that is impacted by geographical distance, partner priorities, commitment (or lack thereof), stability of engagement, and credibility within the relationship. Where there are high levels of risk, high levels of trust are required. As Enos and Morton (2003) maintained, "Trust can be understood as a mutual understanding of the interests of the partners, together with some faith that the partners will stay with the relationship despite obstacles or difficulties that will surely arise" (p. 34), as reflected in the early stages of program development. The establishment of trusting relationships requires significant time investments and continuity of engagement. Many rural communities are confronted with externally driven initiatives that have short timeframes for deliverables, limited funding, and uncertainty associated with sustainability (Bourke et al., 2010). By contrast, this program, at the time of this study, had been operational for six years, had high levels of continuity of engagement across key stakeholders, and service provision through student "team continuums" (Jones et al. 2015a), which the authors propose are features contributing to the sustainability and success of the program. 


\section{Subtheme 3: Professional and faculty satisfaction}

Students described a number of professional learning experiences acquired through their program engagement. Many of these experiences related to higher levels of autonomy of practice: "You need to show a lot of initiative and get things done yourself. Make a lot of decisions that normally you would have someone else making them for you" (FG2: Student 2). This student then described the implications of experiencing this level of autonomy: "It really sets us up for working when we graduate" (FG2: Student 2).

The professional satisfaction derived by the academics through program involvement is reflected in the following quote from the metropolitan academic:

I found it incredibly rewarding being involved in the program. I talk with a lot of people about partnerships, and less than half of them ever amount to anything. This program has been a great success story. It achieves at all levels, individual outcomes for children, outcomes for classroom teachers and schools, community and our education objectives.

Likewise, the rural academic provided detailed insight into the impact of program participation on his or her professional development:

The role has just blossomed. It's an extraordinary job that keeps giving, it's like a magic pudding. I've enjoyed the opportunities to present at conferences, developing skills as a supervisor, to offer supervision in a really innovative model, and impacting ... new graduates and their experience. I'm a complete product of my experiences in this program.

The metropolitan academic described his or her perceptions of program impact from the faculty perspective:

Our faculty has a lot of pride in what happens, what we do, what our students do in Broken Hill and that community relationship. I think it's a great thing for us. Faculties are funny beasts and things that faculties can collectively feel proud about are not all that common.

Subtheme discussion. In their meta-analysis on the impact of service-learning on students, Celio, Durlak, and Dymnicki (2011) identified positive impacts across the domains of attitudes toward education and learning, civic engagement, social skills, and academic outcomes. They identified that servicelearning can benefit students at various educational levels in a multitude of ways, including enhanced self-esteem, positive attitudes toward education and community involvement, and development of community empathy. Sessa et al. (2013) proposed that complex relationships exist within service-learning pedagogies and that these relationships are multiple and bidirectional. Participant insights into relationship complexity associated with the program included community-academic-student, servicelearning, academic-community, academic-student, student-pupil, student-community, student-program and student cohort-program relationships (Jones et al., 2015b).

A lack of evidence of the impact of participation in community-based service-learning for faculties represents an identified gap in the literature (Conway, Amel, \& Gerwien, 2009). Findings from this study suggest that individual student, academic, and faculty benefits can result from participation in these programs and from partnerships between a metropolitan university and rural community agencies.

\section{Subtheme 4: Service-learning implications}

Students provided the following insights into their service-learning experience: 
- It's stressful but satisfying. We can see we have provided a service for these pupils and we're able to achieve our own goals while we're doing it. (FG2: Student 2)

- I think it's very overwhelming at the beginning, just to get started in the first two weeks. Now that we've gone through four weeks, five weeks, gotten into the routine of it, we can see the progression with the pupils as well as with our own professional development. (FG2: Student 5)

Both academics described the tension associated with balancing student learning and service provision. As the metropolitan academic observed:

While the program is about meeting the needs of the schools and the community, it deals with that fine balance between the student learning needs and community needs. Ethically I think when it comes to individual clients, they always come first, and student learning is second.

The rural academic described his or her perception of the main program aim: "The first aim is the service, because regardless of the fact that we are educators, the first thing is the service and always is the service."

Subtheme discussion. The service-learning literature has identified the potential impacts of exposure to marginalized populations and service provision responsibility on student learning outcomes (Jacoby, 2003). Tensions can arise in ensuring equal weighting of service and learning components, especially in communities that experience high levels of unmet need. Ensuring that students' learning is not compromised during their engagement in rural Australian community-based service-learning initiatives is vital. Thus, service and learning objectives must be carefully aligned and potential tensions managed to ensure that the rural context of need informs service activities and that these service activities provide students with the opportunity to consolidate their technical and professionals skills. Increasingly, healthcare delivery is person-centered (Epstein \& Stange, 2010) and community-centered (Fukuzawa, 2013); therefore, supporting students in developing knowledge and skills that enable them to centrally locate service recipients and communities in service provision is essential. Community-based servicelearning may provide a conduit to achieving these outcomes.

\section{Limitations}

The community-campus partnership and service-learning literature are equally concerned with the impact of partnerships and programs on community partners and direct service recipients - in the case of this study, rural children and their families. Impacts on community partners and service recipients went beyond the scope of this study; however, additional research is being undertaken to examine these outcomes. Since this study explored the experiences of a small number of academy participants engaged in one community-based service-learning program being delivered in one rural Australian location, generalizability of the findings is problematic. However, the program described in this study has been adapted for implementation in other rural Australian contexts, and evaluations of these affiliated programs are currently being conducted.

\section{Discussion}

A number of complex and interconnected insights into rural communities were proposed by participants in this study. They described high levels of community insight - or as the authors have termed, "community literate" insight. Within the Australian healthcare context, consumer health literacy is perceived as essential to ensuring high-quality care, and a range of consumer-directed interventions target individual and community health behaviors (Australian Commission on Safety and Quality in Health Care [ACSQHC], 2014). The authors propose that an additional lens is required if substantial and sustainable improvements in rural health outcomes are to be achieved. The lens of health literacy needs to be 
expanded to include a focus on the development of community-literate health students, academics, and professionals. The authors propose the following preliminary definition of community literacy:

having the cognitive and social skills which determine the motivation and ability of health students, academics, and professionals to gain access to, understand, and use community knowledge and information that enables them to be "community intelligent" in the ways they promote and maintain good community engagement practices that reflect and respond to community contexts, needs, priorities and expectations.

Health students, academics, and professionals need to access rural community knowledge to enhance their capacity to effectively engage with communities. The development of community-literate health professionals is just as important as the development of health-literate consumers, and reciprocal investment at the policy, funding, education, and practice levels is required to achieve community-literate health systems and professional outcomes.

\section{Conclusion}

Australian higher education institutions are well positioned to draw on the extensive service-learning literature, experiences, and expertise that has been generated in the United States over the past few decades. However, if Australian higher education institutions are to seriously consider adopting servicelearning as a valid educational pedagogy, then it is imperative that they contextualize service-learning in ways that ensure relevance and responsiveness of the pedagogy to the diverse range of Australian contexts and population needs. In doing so, they must focus on proving robust evidence for the validity of this pedagogy and also be highly cognizant to avoid replicating the United States experience of marginalizing community perspectives in informing the service-learning discourse. In these early stages of service-learning evolution, Australian higher education institutions must ensure that the voices of community partners and service recipients are at the forefront of the movement and that their choices direct service-learning activity. In short, the academy must ensure a community-literate approach to community-based service-learning.

\section{Acknowledgements}

The authors wish to acknowledge New South Wales Department of Education primary schools, Catholic Education primary schools and pre-schools located in far west NSW which are engaged in the program. Funding for expansion of the program was accessed through Health Workforce Australia. The University of Sydney, Faculty of Health Sciences was the foundational university to engage in this program. The University of Sydney, Broken Hill University Department of Rural Health, is funded through the federal Department of Health.

\section{Author Note}

Debra Jones, Broken Hill University Department of Rural Health, University of Sydney; Lindy McAllister, Faculty of Health Sciences, University of Sydney; David Lyle, Broken Hill University Department of Rural Health, University of Sydney.

\section{Correspondence}


Correspondence regarding this article should be addressed to Debra Jones, Director, Primary Health Care, Broken Hill University Department of Rural Health, University of Sydney, Corrindah Court, P.O. Box 457, Broken Hill NSW 2880 Australia. Phone: +61880801239. Email: debra.jones1@health.nsw.gov.au

\section{References}

Allied Health Professionals Australia. (2013). Policy paper: Australia's workforce of allied health professionals. Canberra, Australia: Author.

Astin, A., \& Sax, L. (1998). How undergraduates are affected by service participation. Journal of College Student Development, 39(3), 251-263.

Australian Commission on Safety and Quality in Health Care. (2014). National statement on health literacy: Taking action to improve safety and quality. Sydney, Australia: Author. Retrieved from http://www.safetyandquality.gov.au/publications/health-literacy-national-statement

Beatty, J. (2010). For which future? Exploring the implicit futures of service-learning. International Journal of Organizational Analysis, 18(2), 181-197.

Birbeck, D. (2012). Differentiating service learning in an Australian higher education context. Journal of the Education Research Group of Adelaide, 2(3), 27-32. Retrieved from file://C:/Users/User/Downloads/859-3267-1-PB.pdf

Boeije, H. (2002). A purposeful approach to the constant comparative method in the analysis of qualitative interviews. Quality and Quantity, 36, 391-409.

Bourke, L., Humphreys, J., Wakerman, J., \& Taylor, J. (2010). From "problem-describing" to "problemsolving": Challenging the "deficit" view of remote and rural health. Australian Journal of Rural Health, 18, 205-209.

Bringle, R., \& Hatcher, J. (2009). Innovative practices in service-learning and curricular engagement. New Directions for Higher Education, 147, 37-46.

Brown, B., Heaton, P., \& Wall, A. (2007). A service-learning elective to promote enhanced understanding of civic, cultural and social issues and health disparities. American Journal of Pharmaceutical Education. 71(1). Retrieved from http://www.ncbi.nlm.nih.gov/pmc/articles/PMC1847548/\#

Budhai, S. (2013). Two sides to every story: Exploring community partners' perspectives of their service learning experiences. Journal for Civic Commitment, 20. Retrieved from http://ccncce.org/wpcontent/uploads/2014/06/20 budhai.pdf

Butin, D. (2010). Service-learning in theory and practice: The future of community engagement in higher education. New York: Palgrave Macmillan.

Caspersz, D., Olaru, D., \& Smith, L. (2012). Striving for definitional clarity: What is service learning? Creating an inclusive learning environment: Engagement, equity, and retention. Proceedings of the 21 st Annual Teaching Learning Forum. Perth, Australia: Murdoch University. Retrieved from http://otl.curtin.edu.au/tlf/tlf2012/refereed/caspersz.html

Celio, C. I., Durlak, J., \& Dymnicki, A. (2011). A meta-analysis of the impact of service-learning on students. Journal of Experiential Education, 34(2), 164-181. doi:10.1177/105382591103400205

Cipolle, S. (2010). Service-learning and social justice: Engaging students in social change. Lanham, MD: Rowan \& Littlefield.

Clark, M., McKague, M., McKay, S., \& Ramsden, V. (2015). Deeper learning through service: Evaluation of an interprofessional community service-learning program for pharmacy and medicine students. Journal of Interprofessional Practice and Education, 5(1), 1-25.

Coffey, A., \& Lavery, S. (2015). Service-learning: A valuable means of preparing pre-service teachers for a teaching practicum. Australian Journal of Teacher Education, 40(7), 86-101. Retrieved from http://ro.ecu.edu.au/cgi/viewcontent.cgi?article $=2730 \&$ context $=$ ajte

Conway, J., Amel, E., \& Gerwien, D. (2009). Teaching and learning in the social context: A metaanalysis of service-learning's effects on academic, personal, social and citizenship outcomes. Teaching of Psychology, 36, 233-245. 
Council of Australian Governments. (2009). Investing in the early years: A national early childhood development strategy. An initiative of the Council of Australian Governments. Canberra, Australia: Author.

Creswell, J. (2007). Qualitative inquiry and research design: Choosing among five approaches ( $2^{\text {nd }}$ ed.). London: Sage Publications.

Cruz, N., \& Giles, D. (2000). Where's the community in service-learning research? Michigan Journal of Community Service Learning, 7, 28-34.

Deaville, J., \& Grant, A. (2011). Overcoming the pull factor of convenient urban living: Perceptions of rural general practice. Medical Teacher, 33, e211-e217.

Enos, S., \& Morton, K. (2003). Developing a theory and practice of campus community partnerships. In B. Jacoby \& Associates (Eds.), Building partnerships for service-learning (pp. 20-41). San Francisco, CA: Jossey-Bass.

Epstein, R., \& Stange, K. (2010). Why the nation needs a policy push for patient-centered health care. Health Affairs, 29(8), 1-7

Eyler, J., \& Giles, D. (1999). Where's the learning in service-learning? San Francisco: Jossey-Bass.

Flecky, K. (2011). Foundations of service-learning. In K. Flecky \& L. Gitlow (Eds.), Service- learning in occupational therapy education: Philosophy and practice (pp. 1-12). London, UK: Jones Bartlett.

Fram, S. (2013). The constant comparative analysis method outside of grounded theory. The Qualitative Report, 18(1), 1-25.

Fukuzawa, D. (2013). Achieving healthy communities through community-centered health systems. National Civic Review, Winter, 57-60.

Hammersley, L. (2012). Community based service-learning: Partnerships of reciprocal exchange? Papers from the Australian Collaborative Education Network National Conference. Geelong: AECN. Retrieved from http://www.apjce.org/files/APJCE 14 3 171_184.pdf

Health Workforce Australia. (2013a). A framework for effective clinical placements in rural and remote primary care settings. Adelaide, Australia: Australia. Retrieved from https://www.hwa.gov.au/sites/uploads/ClinicalPlacementFrameworkDoc WEB.pdf

Health Workforce Australia. (2013b). National rural and remote heath workforce innovation and reform strategy. Adelaide, Australia: Author. Retrieved from http://www.hwa.gov.au/sites/uploads/HWA13WIR013 Rural-and-Remote-Workforce-Innovationand-Reform-Strategy v4-1.pdf

Irwin, L., Siddigi, A., \& Hertzman, C. (2007). Early childhood development: A powerful equalizer. Final report for the World Health Organization's Commission on the Social Determinants of Health. Vancouver: Human Early Learning Partnership, University of British Columbia. Retrieved from http://www.who.int/social determinants/themes/ earlychilddevelopment/en/index.html

Jacobson, J., Oravecz, L., Falk, A., \& Osteen, P. (2011). Proximate outcomes of service-learning among family studies undergraduates. Family Science Review, 16(1), 22-33.

Jacoby, B. (Ed). (1996). Service-learning in higher education: Concepts and practices. San Francisco: Jossey-Bass.

Jacoby, B., \& Associates. (Eds.). (2003). Building partnerships for service learning. San Francisco: Jossey-Bass.

Jones, D., McAllister, L., \& Lyle, D. (2015a). Interprofessional academic service-learning in rural Australia: Exploring the impact on allied health student knowledge, skills and practice. A qualitative study. International Journal of Practice-Based Learning in Health and Social Care. 3(2), 1-16.

Jones, D., McAllister, L., \& Lyle, D. (2015b). Stepping out of the shadows: Allied health student and academic perceptions of the impact of a service-learning experience on students' work readiness and employability. Journal of Teaching and Learning for Graduate Employability, 6(1), 66-87.

Jones, D., McAllister, L., Lyle, D., Brunero, C., Webb, T., \& Riley, S. (2015). Improving health and education outcomes for children in remote communities: A cross-sector and developmental evaluation approach. International Journal of Community Research and Engagement. 8(1), 1-22. 
Kendrick, R. (1996). Outcomes of service-learning in an introduction to sociology course. Michigan Journal of Community Service Learning, 3, 72-81.

Lambert, S., \& Loiselle, C. (2008). Combining individual interviews and focus groups to enhance data richness. Journal of Advanced Nursing, 62(2), 228-237. doi:10.1111/j.1365-2648.2007.04559.x

Langworthy, A. (2007). Education for the public good: Is service learning possible in the Australian context? Retrieved from http://www.universityworldnews.com/filemgmt data/ files/Education \%20for $\% 20$ the $\% 20$ Public\%20Good.pdf

Lenk, M. (1997). Discipline-specific knowledge in service-learning: A strategic alliance amongst universities, professional organizations, and non-profit organizations. Michigan Journal of Community Service-Learning. 4, 104-108.

Levett-Jones, T., Lathlean, J., Higgins, I., \& McMillan, M. (2008). The duration of clinical placements: A key influence on nursing students' experience of belongingness. Australian Journal of Advanced Nursing, 26(2), 8-16. Retrieved from http://www.ajan.com.au/Vol26/26-2 Levett Jones.pdf

Lincoln, Y., \& Guba, E. (1985). Naturalistic inquiry. Beverly Hills: Sage.

Mason, J. (2013). Review of Australian Government Health Workforce Programs. Canberra, Australia: Author. Retrieved from: https://www.health.gov.au/internet/main/ publishing.nsf/Content/D26858F4B68834EACA257BF0001A8DDC/\$File/Review\%20of\%20Health $\% 20$ Workforce $\% 20$ programs.pdf

Miles, B., Huberman, M., \& Saldana, J. (2014). Qualitative data analysis: A methods sourcebook (3rd ed.). London: Sage.

Morgan, D. (2014). Pragmatism as a paradigm for social research. Qualitative Inquiry, 20(8), 1045-1053.

National Rural Health Alliance. (2004). A quality rural placement system for health students. Retrieved from http://ruralhealth.org.au/document/quality-rural-placement-system-health-students

New South Wales Department of Education and Communities. (2013). Rural and remote education: A blueprint for action. Sydney, Australia: Author.

Nyden, P., Figert, A., Shibley, M, \& Burrows, D. (1997). Building community: Social science in action. Thousand Oaks, CA: Pine Forge Press.

O'Brien, M., Phillips, B., \& Hubbard, W. (2010). Enhancing the quality of undergraduate allied health clinical education: a multidisciplinary approach in a regional/rural health service. Focus on Health Professional Education: A Multidisciplinary Journal, 12(1), 11-22.

O'Connor, M., Netting, F., \& Thomas, M. (2008). Grounded theory: Managing the challenge for those facing institutional review board oversight. Qualitative Inquiry, 14(1), 28-45.

Patton, M. (2002). Qualitative research and evaluation methods. Thousand Oaks, CA: Sage.

Sandelowski, M. (2000). Focus on research methods: Whatever happened to qualitative description? Research in Nursing and Health, 23, 334-340.

Sessa, V., Grabowski, S., \& Shashidar, A. (2013). Service-learning pedagogy, civic engagement, and academic engagement: Multiple bidirectional relationships in college freshmen. International Journal of Research on Service-Learning and Community Engagement, Fall, 1(1), 23-46.

Simon, A., Pastor, P., Avila, R., \& Blumber, S. (2013). Socioeconomic disadvantage and developmental delay among U.S. children aged 18 months to 5 years. Journal of Epidemiological Community Health, 67(8), 689-695.

Smith, J., Bekker, H., \& Cheater, F. (2011). Theoretical versus pragmatic design in qualitative research. Nurse Researcher, 18(2), 39-51.

Spiers, M., \& Harris, M. (2015). Challenges to student transition in allied health undergraduate education in the Australian rural and remote context: A synthesis of barriers and enablers. Rural and Remote Health. Retrieved from http://www.rrh.org.au/articles/subviewnew.asp?ArticleID=3069

Standing Council on Health. (2013). National primary health care strategic framework. Canberra, Australia: Author. Retrieved from http://www.health.gov.au/internet/main/publishing.nsf/content/6084A04118674329CA257BF0001A3 49E/\$File/NPHCframe.pdf 
197 | International Journal of Research on Service-Learning and Community Engagement

Steinberg, K., Bringle, R., \& Williams, M. (2010). Service-learning research primer. Scotts Valley, CA: National Service-Learning Clearinghouse.

Van Hofwegen, L., Kirkham, S., \& Harwood, C. (2005). The strength of rural nursing: Implications for undergraduate nursing education. International Journal of Nursing Education Scholarship, 2(1), Article 27.

Zlotkowski, E. (1995). Does service-learning have a future? Michigan Journal of Community Service Learning, 2, 123-133. 
